\title{
Bir Tıp Fakültesi Hastanesi Sağlık Çalışanlarında İş Sağlı̆gı-Güvenliği Durumu ve Risk Faktörleri
}

\author{
Occupational Health-safety Status and Risk Factors in Health Workers of a Medical Faculty \\ Hospital
}

\author{
Cansu KARABIBBER ${ }^{\mathrm{a}}$, Gülay SARB ${ }^{\mathrm{b}}$, Beyza KERMAN ${ }^{\mathrm{c}}$, Nazan SAVAŞ ${ }^{\mathrm{d}}$
}

\begin{abstract}
ÖZ Amaç: Sağlık çalışanları iş yerlerinde birçok tehlike, kaza ve hastalık riski ile karşı karşıyadır. Bu çalışmanın amacı bir üniversite hastanesi sağlık çalışanlarının iş sağlığı-güvenliği durumunu saptayarak, risk faktörlerini belirlemektir. Gereç ve Yöntem: Kesitsel nitelikteki çalışma 2017'de Hatay Mustafa Kemal Üniversitesi Tıp Fakültesi Hastanesi'nde yapılmıştır. Araştırma evreni 855 sağlı çalışanı olup, üç günlük veri toplama sürecinde \%30,4 (260)'üne ulaşılmıştır. Araştırmaya katılmayı kabul eden 209 (\%80,0) kişiye anket ve "Hastanelerde Çalışan Sağlık Personeli İş Güvenliği Ölçeği” uygulanmıştır. Ölçek likert tipinde olup, 7 faktörden oluşmaktadır. Ölçekten maksimum 6 puan alınmakta, puan 6'ya yaklaştıkça iş güvenliğinin sağlandığı yönünde yorumlanmaktadır. Analizlerde Student-T, tek yönlü varyans ve Pearson Korelasyon testleri kullanılmıştır. Bulgular: Sağlık personelinin yaş ortalaması 30,8土6,1, \%61,2'si kadın, \%37,8'si hemşire ve \%24,4'ü hekimdir. \%72,7'si el dezenfektanını, \%82,8'i eldiveni kullanmakta; \%93,7'si sabuna, \%90,3'ü el dezenfektanına, \%87,9'u

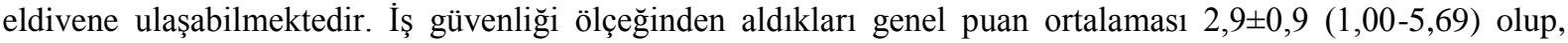

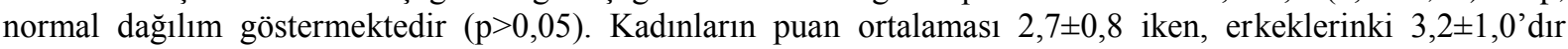
$(\mathrm{p}=0,002)$. Çocuğu olanların puan ortalaması daha yüksektir $(\mathrm{p}=0,003)$. Dahili branştakilerin puan ortalaması $2,69 \pm 0,9$ iken cerrahi branştakilerin 3,17 $\pm 0,9$, temel branştakilerin ise $2,72 \pm 0,9^{\prime} \mathrm{dir}(\mathrm{p}=0,004)$. En düşük puanlar sırasıyla Faktör 1 (Mesleki Hastalıklar ve Şikayetleri) ve Faktör 4'den (Yönetsel Destek ve Yaklaşımlar) alınmış̧ır. Sonuç: Hastane sağlık çalışanlarının iş güvenliği ölçeği puan ortalaması tam puanın yarısına yakındır. Kadınların, dahili branş çalışanlarının ve çocuğu olmayanların iş sağlığı-güvenliği algısı daha düşüktür.
\end{abstract}

Anahtar Sözcükler: Hastane, iş sağlığı, sağlık hizmetleri, sağlık çalışanları

ABSTRACT Aim:Health care workers are susceptible to numerous risks of danger, illness and accidents. The aim is to determine the condition of occupational health-safety and risk factors in a university hospital healthcare workers. Materials and Methods: Across-sectional study was conducted at Hatay Mustafa Kemal University Hospital in 2017. We reached $30.4 \%$ (260 healthcare worker) of there search population (855) in three days of data collection, 209 (80,0\%) persons were participated. The survey and "Healthcare Worker's Work Safety Scale" we reapplied. The scale is likert type, consist of 7 factors and maximum 6 points. Student-T, One Way ANOVA and Pearson Correlation tests were used. Results: The mean age of healthworkers is $30,8 \pm 6,1,61,2 \%$ is woman, $37,8 \%$ is nurse and $24,4 \%$ is physcian. $72,7 \%$ of them are using hand sanitizer, $82,8 \%$ of them are using hand glove; $93,7 \%, 90,3 \%$ and $87,9 \%$ of them find soap, hand sanitizer and glov eavailable respectively. The mean score of the healthcareworkers on scale is $2,9 \pm 0,9(1,00-5,69)$ and shows normal distribution $(\mathrm{p}>0,05)$. While woman's mean score is $2,7 \pm 0,8$, man's is $3,2 \pm 1,0(\mathrm{p}=0,002)$. The mean score of them in medical disciplines is $2,69 \pm 0,9$, surgical disciplines is $3,17 \pm 0,9$ and basic sciences disciplines is $2,72 \pm 0,9(\mathrm{p}=0,004)$. They having child have high mean score $(\mathrm{p}=0,003)$. The lowest mean scores of the scale are on Factor-1 (occupational diseases and complaints) and Factor-4 (administrative support and approaches). Conclusion: Hospital healthworkers' job security score average is close to half of full score. Perception on occupational health and safety of woman, in medical disciplines and without having a child are lower.

Keywords: Hospital, occupational health, health services, healthcare workers

\section{Giriş ve Amaç}

İş sağlığ 1 ve güvenliği, iş yerinde işin yürütülmesi sırasında çeşitli nedenlerden kaynaklanan sağlığa zarar verebilecek koşullardan korunmak amaciyla yapılan sistemli ve bilimsel çalışmalardır (1). İş yerlerinde iş sağlığı ve güvenliğinin sağlanmasıyla çalışanla- rın sadece fiziksel olarak sağlıklı olması değil, uyumlu ve verimli çalışması, psikolojik ve ruhsal yönden de sağliklı ve tatmin olması hedeflenmektedir (2). İş sağllğ ve güvenliği iş yerlerinde etkinlik ve verimliliği arttırmada da rekabet ortamının tanımlayıcılarından kabul edilmiştir (3).

Geliş Tarihi/Received:15-12-2017/ Kabul Tarihi/Accepted:25-04-2018

a Arş. Gör. Dr. Mustafa Kemal Üniversitesi Halk Sağlı̆̆ 1 Anabilim Dalı / Hatay, ORCID: 0000-0001-7350-3918

${ }^{\text {b} A r s ̧ . ~ G o ̈ r . ~ D r . ~ M u s t a f a ~ K e m a l ~ U ̈ n i v e r s i t e s i ~ H a l k ~ S a g ̆ l ı g ̆ ı ~ A n a b i l i m ~ D a l ı ~ / ~ H a t a y, ~ O R C I D: ~ 0000-0001-7620-6783 ~}$

${ }^{c}$ Arş. Gör. Dr. Mustafa Kemal Üniversitesi Halk Sağlığı Anabilim Dalı / Hatay, ORCID 0000-0003-3360-1630

d Prof. Dr. Mustafa Kemal Üniversitesi Halk Sağlığı Anabilim Dalı / Hatay, ORCID: 0000-0003-1427-6959

Sorumlu Yazar/ Correspondence: Prof. Dr. Nazan Savaş, Mustafa Kemal Üniversitesi Halk Sağlı̆̆ı Anabilim Dalı Hatay 
Yapılan araştırmalarda hastanelerdeki infeksiyonlar, ilaçlar ve malzemelerin yarattığ 1 tehlikeler, atıklar, ergonomik tasarım eksiklikleri, çalışma koşulları ve malzeme yetersizliği, iş yükü fazlalığı, çalışanların dikkatsiz davranışları vb. nedenlerle sağlık çalışanlarının birçok tehlike, kaza ve hastalık riski ile karşı karşıya kaldığı görülmektedir (25). Bu nedenle hastanelerde güvenli ve sağllklı bir ortam oluşturma eğilimi günümüzde hızla ivme kazanmıştır (2). Uluslararası Ortak Komisyonu (Joint Commission International) ve TC Sağlık Bakanlığı'nın yayınladığı hizmet kalite standartlarında hasta ve çalışan güvenliğine yönelik çıkarılan yönetmelikte hastanelerde hasta güvenliğinin yanı sıra çalışan güvenliğinin sağlanmasına yönelik faaliyetlere ilişkin kriterlere de yer verilmiştir $(6,8)$.

Sağlık çalışanlarının sağlığını etkileyen mesleki maruziyet kaynaklı riskler biyolojik, fiziksel, ergonomik, kimyasal ve psikososyal olmak üzere gruplandırılmıştır. Amerikan Ulusal Mesleki Sağlık ve Güvenlik Enstitüsü hastanelerde 29 çeşit fiziksel, 25 çeşit kimyasal, 24 çeşit biyolojik, 6 çeşit ergonomik ve 10 çeşit psikososyal mesleki maruziyet kaynaklı risk olduğunu bildirmiştir $(9,10)$. Sağlık çalışanlarının yoğun çalışma temposu, uzun süreli, kesintisiz çalışma ve iş gerilimi diğer iş kollarında çalışanlara göre çok daha çeşitli meslek riskleri ile karşılaşmasına ve sağlık durumlarının olumsuz etkilenmesine yol açmaktadır. Hastane sağlık çalışanlarının en sık karşılaştığı mesleki sağlık sorunlarının infeksiyon hastalıkları, tüberküloz, bel ağrısı, varis, iş stresi, kas-iskelet sistemi yaralanmaları, şiddet, kötü muamele, kesici-batıc1delici cisim yaralanmaları ve lateks alerjisi olduğu, bu sorunların son yirmi yıldır ciddi boyutlara ulaştı̆g 1 belirtilmektedir (9). Oysa sağlık hizmeti verenin sağlıklı olması, sağlık hizmeti alanın sağlığını ve yaşam kalitesini de arttırmaktadır (10).

Uluslararası Hemşireler Birliği (International Council of Nurses (ICN)) 2006'da sağlık çalışanlarının maruz kaldığı sağlık sorunlarının sadece kendileri için değil aynı zamanda aileleri, çalışma arkadaşları ve hizmet verdiği hastaları için de önemli olduğu bu nedenle hastane sağlık çalışanlarının sağlık hizmeti almasının zorunluluğuna vurgu yapılmaktadır (9). Ayrıca yapılan pek çok araştırma ve bilimsel raporlarda sağlik sisteminde özelleştirmenin artmasıyla sağlık çalışanlarının karşılaşabilecekleri mevcut/olası tehlike ve risklerin, meslek hastalıklarının, iş kazalarının, işe bağlı sağlık sorunlarının, sakatlık ve iş görmezlik durumlarının arttı̆̆ oluştuğu ve çeşitliliğin çoğaldığ gösterilmiştir (11). Altıok ve arkadaşlarının bir çalışmasında sağlık çalışanlarının bir kısmının çalışan sayısının yetersizliğine bağlı olarak ağır işlerde ve düzensiz ya da uygunsuz koşullarda çalıştırıldığ işlerde çalıştırıldığ 1 belirtilmiştir (12).

Ülkemiz sağlık çalışanları büyük oranda hastanelerde istihdam edildiği halde, sağlık ve güvenlik hizmetlerini yeterince alamamakta, meslek hastalıkları, iş kazaları ve işe bağlı sağlık sorunlarının kayıtları bulunmamaktadır (12).

\section{Gereç ve Yöntem}

\section{Araştırmanın Amacı}

Çalışmamızda bir üniversite hastanesinde çalışan sağlık personelinin iş güvenliği durumu "Hastanelerde Çalışan Sağlık Personeli İş Güvenliği Ölçeği” ile saptanarak ilişkili sosyodemografik ve mesleki risk faktörlerinin belirlenmesi amaçlanmıştır.

\section{Araştırmanın Evren ve Örneklemi}

Kesitsel nitelikte olan bu çalışmanın evreni Hatay Mustafa Kemal Üniversitesi Araştırma ve Uygulama Hastanesi'nde çalışan 110 öğretim üyesi, 138 araştırma görevlisi doktor, 202 hemşire ve 405 diğer sağlık personeli (sağlık memuru-teknisyeni-acil tıp teknisyeni, biyolog, diyetisyen, eczacı vb) olmak üzere toplam 855 sağlık çalışanıydı. Çalışmamızda örnek seçilmedi. Üç gün veri toplama sürecinde $260(\% 30,4)$ çalışana ulaşıldı, bunların \%80,0'1 (209) çalışmaya katılmayı kabul etti.

\section{Veri Toplama Araçları}

Veri toplama aracı olarak araştırmacılar tarafindan oluşturulan 25 soruluk anket formu ile "Hastanelerde Çalışan Sağlık Personeli İş Güvenliği Ölç̧eği” kullanıldı.

Anket Formu: Anketin ilk kısmında sağl1k çalışanlarının sosyodemografik ve mesleki özelliklerini (cinsiyet, yaş, medeni durum, çocuk sayısı, mesleği, hastanede çalıştığı bölüm ve birim, aylık gelir, çalıştığı süre, vardiya, nöbet tutma durumu ve sıklığı) sorgulayan sorular soruldu. İkinci kısmında ise çalışanların iş güvenliğini belirlemek amacıyla kişisel koruyuculara (sabun, el dezenfektanı, eldiven, önlük) ulaşılıp ulaşamadığı, ulaşamadığında 
veya herhangi bir maruziyet durumunda (iğne batmas1, ampul kırma, kimyasal maddenin inhaler yada direk temas yoluyla bulaşı) ne yaptığı, iş sağlığ 1 ve güvenliği için daha önce bilgilendirilip bilgilendirilmediği, injeksiyon uygulama sırasında riskli davranışları yapıp yapmadığı, cilt/göz/açık yaraya kimyasal sıçradığında ne yaptığı gibi tutum ve davranış soruları soruldu.

Hastanelerde Çalışan Sağllk Personeli İş Güvenliği Ölçeği: Öztürk ve Babacan tarafından 2012 y1lında geliştirilen ölçek 6'lı Likert tipinde olup 45 madde ve 7 faktörden oluşmaktadır (13). Her madde için alınan puan minimum 1 (Kesinlikle katılmıyorum), maksimum 6 puandır (Tamamen katıliyorum). Ölçekten en düşük 45 , en yüksek 270 puan alınmakta, ancak 6'lı puana (1-6 puan) dönüştürülmüş halinin kullanılması önerilmektedir. Ölçek için belirli bir kesim noktası belirlenmemiş olup alınan puan 6'ya yaklaştıkça iş güvenliğinin sağlandığı yönünde yorumlanmaktadır. Ölçek faktörlerinin ne anlama geldiği ve faktörlerdeki madde sayıları şöyledir;

Faktör 1: Mesleki Hastalıklar ve Şikayetleri (13 Madde)

Faktör 2: Sağlık Taraması ve Kayıt Sistemleri (6 Madde)

Faktör 3: Kazalar ve Zehirlenmeler (5 Madde)

Faktör 4: Yönetsel Destek ve Yaklaşımlar (7 Madde)

Faktör 5: Malzeme Araç ve Gereç Denetimi (5 Madde)

Faktör 6: Koruyucu Önlemler ve Kurallar (5 Madde)

Faktör 7: Fiziksel Ortam Uygunluğu (4 Madde)

\section{Verilerin Toplanması}

Mart-Nisan 2017 döneminde yapılan araştırmada yüzyüze görüşme tekniği kullanılarak veriler topland. Veri toplama süresi veri toplayan araştırmacıların (intörn doktor) eğitim müfredatına göre üç gün olarak belirlendi.

\section{Verilerin Değerlendirilmesi}

Verilerin istatistiksel analizinde tanımlayıc1 istatistikler, Kolmogorov Sminnow, Student t, tek yönlü varyans, Pearson ve Parsiyel Korelasyon analizleri kullanıldı. $\mathrm{p}<0,05$ önemli kabul edildi. Analizlerde SPSS 20.0 paket programından yararlanıldı.

\section{Araştırmanın Etik Yönü}

Araştırmada insan ya da hayvan materyal örneği kullanılmadığ 1 , sadece anket uygulandığ 1 için klinik araştırmalar yerel etik kurulundan onay alınmadi.

\section{Bulgular}

Araştırmaya katılan hastane sağlık

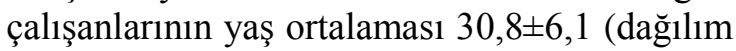
aralığ $20-51$ ) olup, \%61,2'si kadın ve \%63,1'i evliydi. Mesleğe göre bakıldığında; \%24,4'ünün doktor, \%37,8'inin hemşire olduğu, \%46,9'unun dahili, \%43,5'inin de cerrahi bilimlerde çalıştığı saptandı. Araştırma grubunun \%51,2'si servislerde çalışırken, \%80,4'ü gündüz çalışıyordu. Aylık nöbet sayısı ortalama $5,6 \pm 0,2$ idi. Meslekte çalışma süresi ortalama $6,4 \pm 4,4$ yıl, hastanede çalışma süresi ortalama 4,8 $\pm 3,1$ yıl (dağılım aralığı 1-16), haftalık

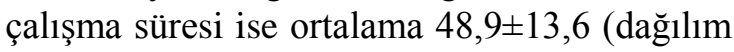
aralığ 11-118) saat idi (Tablo 1).

İş sağllğ 1 ve güvenliği kapsamında sorulan sorulara verilen yanıtlara göre sağl1k çalışanlarının sabun, el dezenfektanı, eldiven ve maske kullanım sıklıkları Grafik 1'de gösterildi. Buna göre sağlık çalışanlarının $\% 72,7$ 'si el dezenfektanını, \%82,8'i eldiveni ve \%36,4'ü maskeyi genellikle kullandığını belirtti. Doktorların \%82,0'1, hemşirelerin $\% 81,0$ '1 ve diğer sağlık çalışanlarının \%85,0'1 eldiveni genellikle kullanmaktayd.

Sağlık çalışanlarına hastanede koruyu$\mathrm{cu}$ malzemelere ulaşım durumu sorguland1ğında; sabuna \%93,7'si, el dezenfektanına $\% 90,3$ 'ü, eldivene $\% 87,9^{\prime} \mathrm{i}$ ve maskeye $\% 74,4$ 'ü sıklıkla/her zaman ulaşabildiğini bildirdi (Tablo 2).

Araştırmaya katılan hastane çalışanlarının riskli durumlarda tutum ve davranışlarını ölçme amaciyla sorulan sorulara verilen yanıtlara göre; \%31,9'u enjektörü kullandıktan sonra iğne ucunu usulüne uygun olmayan biçimde atıyor, \%7,7'si işlem öncesi ve sonrası ellerini yıkamıyor, \%5,9'u kişisel koruyucu malzemelere ulaşamadığında koruyu-cu malzeme olmadan işlemi uyguluyordu (Tablo 3). Doktorların $\% 27,1$ 'i, hemşirelerin $\% 20,5$ 'i, diğer sağlık personelinin ise \% 48,6 's1 enjektörü kullandıktan sonra iğne ucunu usulüne uygun olmayan biçimde at1yordu $(p=0,001)$. Hepatit B'ye karşı bağ 1 şklık durumu değerlendirildiğinde; $\% 6,8$ 'i bağışık değildi ve $\% 10,1$ 'i de bağışıklık durumunu bilmiyordu.

Araştırmaya katılanların İş Güvenliği Ölçeği'nden aldıkları genel puan ortalaması 6 tam puan üzerinden $2,91 \pm 0,90$ (dağılım aralığı 
1,00-5,69) olup, alınan puanlar normal dağılım gösteriyordu ( $>0,05)$. Ölçeğin alt faktörleri değerlendirildiğinde; en düşük puan ortalaması Faktör 1'den alınmıştı. Faktör 1'in puan ortalamas1 2,29 $\pm 1,06$, Faktör 4'ün puan ortalamas $2,47 \pm 1,13$ idi. Diğer faktörlerin

Tablo1. Hastane Sağllk Çalışanlarının Sosyodemografik ve Çalışma Durumları

\begin{tabular}{|c|c|c|}
\hline & Sayı (n) & $\%$ \\
\hline \multicolumn{3}{|l|}{ Cinsiyet } \\
\hline Kadın & 128 & 61,2 \\
\hline Erkek & 81 & 38,8 \\
\hline \multicolumn{3}{|l|}{ Medeni Durum } \\
\hline Evli & 132 & 63,1 \\
\hline Bekar & 76 & 36,4 \\
\hline Boşanmış & 1 & 0,5 \\
\hline \multicolumn{3}{|l|}{ Cocuk Sahibi Olma } \\
\hline Var & 111 & 53,1 \\
\hline Yok & 67 & 32,1 \\
\hline Belirtmemiş & 31 & 14,8 \\
\hline \multicolumn{3}{|l|}{ Meslek } \\
\hline Doktor & 51 & 24,4 \\
\hline Hemşire & 79 & 37,8 \\
\hline Diğer & 79 & 37,8 \\
\hline \multicolumn{3}{|l|}{ Çalışılan Bölüm } \\
\hline Dahili & 98 & 46,9 \\
\hline Cerrahi & 91 & 43,5 \\
\hline Temel & 20 & 9,6 \\
\hline \multicolumn{3}{|l|}{ En çok çalıșlan birim } \\
\hline Servis & 107 & 51,2 \\
\hline Poliklinik & 17 & 8,1 \\
\hline Yoğun bakım & 28 & 13,4 \\
\hline Acil & 16 & 7,7 \\
\hline Laboratuvar & 16 & 7,7 \\
\hline Ameliyathane & 14 & 6,7 \\
\hline Diğer & 8 & 3,8 \\
\hline Belirtmemiş & 3 & 1,4 \\
\hline \multicolumn{3}{|l|}{ Çalışılan birim } \\
\hline Servis & 108 & 51,7 \\
\hline Poliklinik & 26 & 12,4 \\
\hline Yoğun bakım & 29 & 13,9 \\
\hline Acil & 11 & 5,2 \\
\hline Laboratuvar & 14 & 6,7 \\
\hline Ameliyathane & 10 & 4,8 \\
\hline Diğer & 11 & 5,3 \\
\hline \multicolumn{3}{|l|}{ Çalışılan vardiya } \\
\hline Gündüz & 168 & 80,4 \\
\hline Gece & 37 & 17,7 \\
\hline Belirtmemiş & 4 & 1,9 \\
\hline \multicolumn{3}{|l|}{ Nöbet tutma } \\
\hline Evet & 124 & 59,3 \\
\hline Hayır & 80 & 38,3 \\
\hline Belirtmemiş & 5 & 2,4 \\
\hline
\end{tabular}

genel puan ortalamaları 3,00'dan büyük bulundu. Genel ve tüm Faktörlerin puan ortalamaları Grafik 2'de gösterildi.

Cinsiyete göre karşılaştırıldığında; kadınların iş sağlı̆ğ ve güvenliği genel puan ortalamasi $(2,73 \pm 0,8)$ erkeklerin puan ortalamasindan $(3,21 \pm 1,0)$ yüksek bulundu $(\mathrm{p}=0,002)$ (Tablo 4). Genel puan ortalaması dahili branş çalışanlarında $2,69 \pm 0,9$, cerrahi branş çalışanlarında $3,17 \pm 0,9$ ve temel branş çalışanlarında $2,72 \pm 0,9(\mathrm{p}=0,004)$ olup, dahili ve cerrahi branş puanları arasındaki fark önemliydi $(\mathrm{p}=0,003)$. Çocuk sahibi olanların
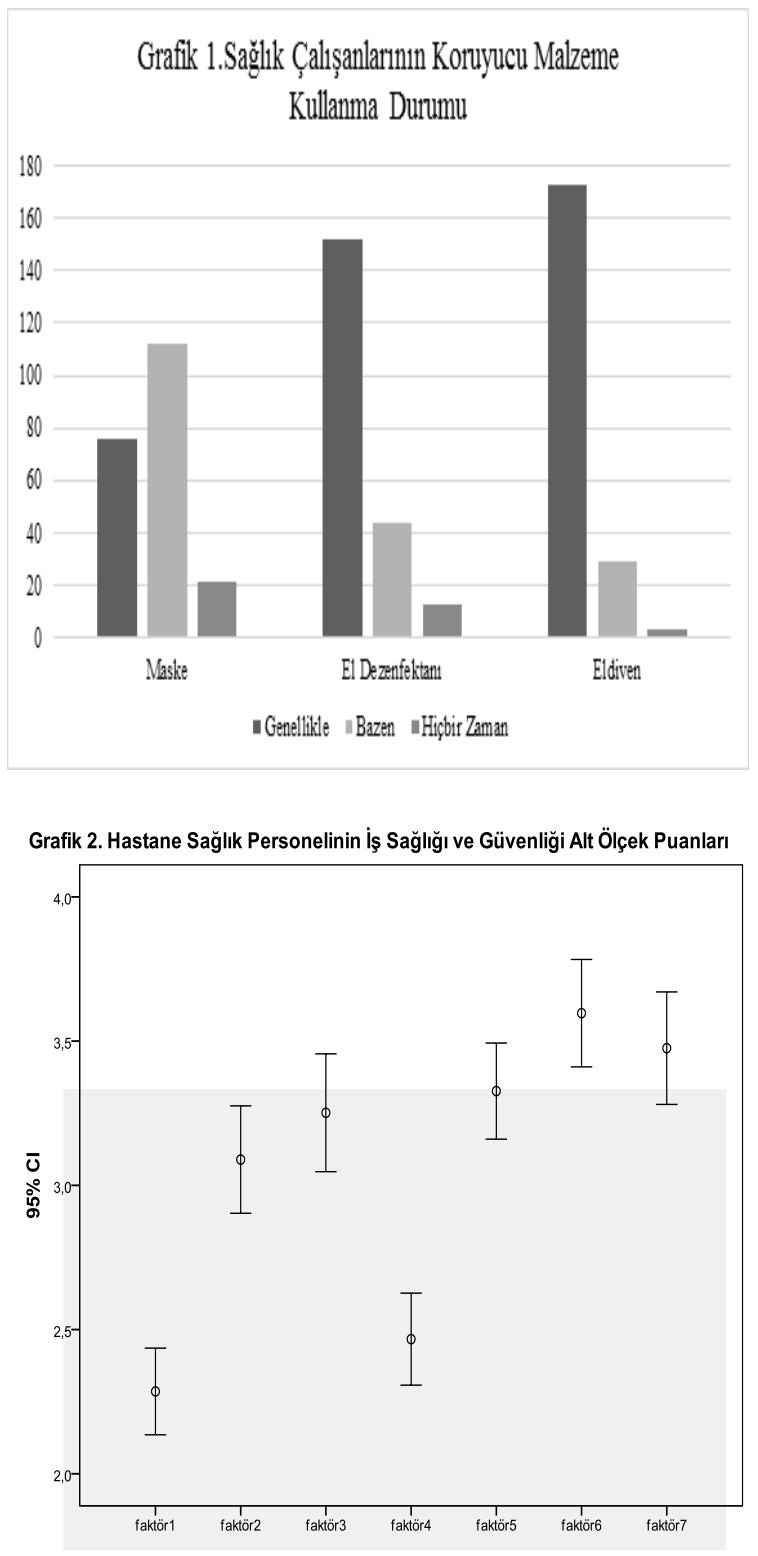
Tablo 2. Hastanede Koruyucu Malzemelere Ulaşım Durumu ( $\mathrm{n}=207)$

\begin{tabular}{lcccc}
\hline & $\begin{array}{c}\text { Hiçbir zaman } \\
\text { Sayı (\%) }\end{array}$ & $\begin{array}{c}\text { Nadiren } \\
\text { Sayı (\%) }\end{array}$ & $\begin{array}{c}\text { Siklıkla } \\
\text { Sayı (\%) }\end{array}$ & $\begin{array}{c}\text { Her zaman } \\
\text { Sayı }(\%)\end{array}$ \\
\hline El dezenfektanı & $4(1.9)$ & $9(4,3)$ & $75(36,2)$ & $119(57,5)$ \\
\hline Maske & $5(2,4)$ & $15(7,3)$ & $92(44,4)$ & $95(45,9)$ \\
\hline Eldiven & $9(4,3)$ & $44(21,3)$ & $61(29,5)$ & $93(44,9)$ \\
\hline
\end{tabular}

Tablo- 3. Hastane Sağlık Personelinin Bazı Riskli Durumlardaki Tutum ve Davranışları

\begin{tabular}{|c|c|c|c|}
\hline & & Say 1 & $\%$ \\
\hline \multirow[t]{3}{*}{ İşlem öncesi ve sonras1 ellerimi ( $\mathrm{n}=207$ ) } & Y1karım & 188 & 90,0 \\
\hline & Bazen y1karım & 5 & 2,3 \\
\hline & Y1kamam & 16 & 7,7 \\
\hline \multirow{3}{*}{ Ampülü nasıl kırarsınız (n=197) } & Çıplak elle & 73 & 37,0 \\
\hline & Eldivenle & 82 & 41,6 \\
\hline & Pamuk/peçete ile & 42 & 21,4 \\
\hline \multirow{2}{*}{$\begin{array}{l}\text { Enjektörü kullandıktan sonra iğne ucunu } \\
(\mathrm{n}=204)\end{array}$} & Kapatarak atarım & 65 & 31,9 \\
\hline & Kapatmadan atarım & 139 & 68,1 \\
\hline \multirow{5}{*}{$\begin{array}{l}\text { Kişisel koruyucu malzemelere } \\
\text { ulaşmadığımda; }(n=204)\end{array}$} & Başka birimden tedarik ederim & 119 & 58,3 \\
\hline & İşi başkasına devrederim & 6 & 2,9 \\
\hline & Yönetime bildiririm & 48 & 23,5 \\
\hline & İşlemi uygulamam & 19 & 9,4 \\
\hline & İşlemi uygularım & 12 & 5,9 \\
\hline \multirow{4}{*}{$\begin{array}{l}\text { Cilt, göz, açık yaraya kimyasal sıçradığında; } \\
(\mathrm{n}=209)\end{array}$} & Bir şey yapmam & 9 & 4,3 \\
\hline & Hemen yıkarım & 181 & 86,6 \\
\hline & Silerim & 11 & 5,3 \\
\hline & İşlem bittikten sonra yıkarım & 8 & 3,8 \\
\hline \multirow[t]{4}{*}{ Hepatit B'ye karşı bağışıklık durumu;(n=207) } & Var ( aşı ile) & 164 & 79,2 \\
\hline & Var ( hastalığı geçirdim) & 8 & 3,9 \\
\hline & Yok & 14 & 6,8 \\
\hline & Bilmiyorum & 21 & 10,1 \\
\hline
\end{tabular}

puan ortalaması 3,08 $\pm 0,9$ iken, çocuk sahibi olmayanların 2,61 $\pm 0,8$ idi $(\mathrm{p}=0,003)$. Meslek, vardiya usulü çalışma, en çok çalışılan birim, şu an çalışılan birim, nöbet tutma, sağlık riskleri hakkında bilgilendirilme ve personele iş dişı sorumluluk yüklenilmesi ile iş sağlı̆̆ı ve güvenliği ölçeğinden alınan genel puan ortalamaları arasında önemli ilişkiler saptanmadi $(\mathrm{p}>0,05)$.

Ölçekten elde edilen toplam puan ortalaması ile meslekte çalışma süresi, hastanede çalışma süresi, haftalık çalışma süresi, aylık gelir, yaş ve nöbet sayısı ile önemli korelasyonlar saptanmadı $(\mathrm{p}>0,05)$. Yaşın kafa karıştırıcı faktör olabileceği düşünülerek yaş kontrol altına alınmasıyla yapılan parsiyel korelasyon analizinde de ölçek puanı ile tüm bu değişkenler arasında korelasyonlar saptanmadı $(\mathrm{p}>0,05)$.

\section{Tartışma}

Hastanelerde iş sağlığı ve güvenliği kapsamında el hijyeninin sağlanması sağlık çalışanlarının sorumluluğunda olan öncelikli uygulamalardan biridir. Çalışmamızda sağlık personelinin \%90,0'1nın hastanede işlem öncesi ve sonrasında ellerini yıkadığı, \%72,7'sinin el dezenfektanını, \%82,8'inin eldiveni, \%36,4'ünün maskeyi genellikle kullandığı saptanmıştır. Deveci ve arkadaşlarının yaptığı bir çalışmada ise üniversite hastanesindeki temiz- 
Tablo 4. Hastane Sağlık Personelinin İş Sağlığı ve Güvenliği Ölçeğinden Aldıkları Puanların Sosyodemografik ve Mesleki Özelliklere Göre Durumu

\begin{tabular}{|c|c|c|c|c|}
\hline & & \multicolumn{2}{|c|}{ Ölçeği Puanı } & \multirow[t]{2}{*}{$\mathrm{P}$} \\
\hline & & Min-Mak & Ortalama & \\
\hline \multirow[t]{2}{*}{ Cinsiyet } & Kadın & $1,00-4,76$ & $2,7 \pm 0,8$ & \multirow[b]{2}{*}{$0,002^{*}$} \\
\hline & Erkek & $1,00-5,69$ & $3,2 \pm 1,0$ & \\
\hline \multirow[t]{3}{*}{ Meslek } & Doktor & $1,04-5,69$ & $2,7 \pm 1,0$ & \multirow{3}{*}{$0,504 * *$} \\
\hline & Hemşire & $1,36-5,09$ & $2,9 \pm 0,8$ & \\
\hline & Diğer & $1,00-5,64$ & $2,9 \pm 1,0$ & \\
\hline \multirow[t]{3}{*}{ Çalıştığı Bölüm } & Dahili & $1,00-5,18$ & $2,6 \pm 0,9$ & \multirow{3}{*}{$0,004 * *$} \\
\hline & Cerrahi & $1,00-5,69$ & $3,1 \pm 0,9$ & \\
\hline & Temel & $1,49-4,71$ & $2,7 \pm 0,9$ & \\
\hline \multirow[t]{2}{*}{ Vardiya } & Gündüz & $1,00-5,60$ & $2,9 \pm 0,9$ & \multirow[b]{2}{*}{$0,306^{*}$} \\
\hline & Gece & $1,60-4,60$ & $2,7 \pm 0,8$ & \\
\hline \multirow[t]{2}{*}{ Çalışılan birim } & Servis & $1,00-4,80$ & $3,0 \pm 0,8$ & \multirow[b]{2}{*}{$0,12 *$} \\
\hline & Diğer & $1,00-5,60$ & $2,7 \pm 1,0$ & \\
\hline \multirow[t]{2}{*}{ Şu an çalışılan birim } & Servis & $1,00-4,80$ & $3,0 \pm 0,8$ & \multirow[b]{2}{*}{$0,11 *$} \\
\hline & Diğer & $1,00-5,60$ & $2,7 \pm 1,1$ & \\
\hline \multirow[t]{2}{*}{ Nöbet tutma durumu } & Evet & $1,00-5,10$ & $2,9 \pm 0,9$ & \multirow[b]{2}{*}{$0,87 *$} \\
\hline & Hayır & $1,00-5,60$ & $2,85 \pm 0,9$ & \\
\hline \multirow{2}{*}{$\begin{array}{l}\text { Sağlık riskleri hakkında } \\
\text { bilgilendirilme }\end{array}$} & Var & $1,00-5,60$ & $2,93 \pm 1,0$ & \multirow{2}{*}{$0,23^{*}$} \\
\hline & Yok & $1,00-4,40$ & $2,72 \pm 0,8$ & \\
\hline \multirow{2}{*}{$\begin{array}{l}\text { Hastanede işi dışında } \\
\text { sorumluğu }\end{array}$} & Var & $1,00-5,60$ & $2,86 \pm 0,9$ & \multirow[t]{2}{*}{$0,23 *$} \\
\hline & Yok & $1,00-5,60$ & $3,03 \pm 0,9$ & \\
\hline \multirow[t]{2}{*}{ Çocuk } & Var & $1,00-5,60$ & $3,08 \pm 0,9$ & \multirow[t]{2}{*}{$0,003^{*}$} \\
\hline & Yok & $1,30-5,10$ & $2,61 \pm 0,8$ & \\
\hline
\end{tabular}

lik çalışanlarının tümünün $(\% 100)$ çalışmaları sırasında eldiven, \%11.6'sının bone/başlık \%8.9'unun ise maske kullandığı bildirilmiştir(14). Pitted D'nin konuyla ilgili yaptığı çalışmalarda hastanede el hijyenine riayet etmemenin \%19-84 arasında değiştiği gösterilmiştir (15-17). Ankara' da yapılan bir çalışmada katılımcıların el temizliği kurallarına uyum oranı (el yıkama veya el antisepsisi ile ovma) \%8.9 ve el temizliğinde alkol bazlı el dezenfektanı kullanma oranı \%11 olarak saptanmıştır (18).

Çalışmamızda katılımcıların \%82,8'-inin eldiveni genellikle kullandığ 1 görülmüştür. Altıok'un 2008 yılında yaptığı araştırmada sağlık çalışanlarının \%72,0'ının, üniversite hastanesinde çalışanların ise \%78.8'inin sıklıkla/her zaman eldiven kullandığı saptanmıştır (19). Bizim çalışmamızda eldiven kullanım sıklığının Altıok'un çalışmasına göre daha yüksek bulunması günümüzde hastane ortamında eldiven kullanımının arttığını düşündürmekle beraber, hala istenilen düzeyde olmadığını da göstermektedir.

Çalışmamızda eldiven kullanımı mesleklere göre değerlendirildiğinde; doktorların \%82,0'ının, hemşirelerin \%81,0'ının ve diğer sağlık personelin \%85,0'ının siklıkla/her zaman eldiven kullandığı saptanmıştır. Çalışmamızda mesleklerin eldiven kullanım sıklığının birbirine benzer olduğu ancak istenilen düzeyde olmadığı görülmüştür. Çalışkan ve Akdur'un 2001yılında Ankara'da 
hemşireler üzerine yaptığı çalışmada ise eldiven kullanımı bizim çalışmamıza göre daha düşük (\%62.8) bulunmuştur (20). Sönmezer MÇ ve arkadaşlarının 2014 yılında yaptığı araştırmada ise el temizliğine uyumun en iyi hemşirelerde (\%75) olduğu, bunu sirasiyla uzman doktorların (\%20) ve asistan doktorların (\%5) izlediği görülmüştür(18). Bizim çalışmamız dahil, farklı zamanlarda yapılan bu çalışmalara göre ülkemizde hemşirelerde el hijyeni bilincinde gelişme olduğu görülmektedir. İngiltere'de 2006 yılında yapılan bir çalışmada hastanede eldiven kullanım sıkılığının doktorlarda $\% 71$, hemşirelerde $\% 91$ olduğu gösterilmiştir(21). $\mathrm{Bu}$ durum İngiltere'de hastanelerde iş sağlığ uygulamalarında hemşirelerin daha özenli davranmalarından, daha eğitimli olmalarından ya da daha iyi denetim mekanizmalarına tabi tutulmalarından kaynaklanıyor olabilir.

Enjeksiyon uygulamalarında işlem bitiminde enjektör uçlarının bükülmeden ve ağzı kapatılmadan güvenli bir şekilde sarı infekte atık kutularına atılması gerekmektedir. Çalışmamızda sağlık personelinin \%31,9'unun injeksiyonu uyguladiktan sonra iğne ucunu usulüne uygun olmayan biçimde attığı saptanmıştır. En çok usulüne uygun olmayan atım sırasıyla; diğer sağlık personelinde $(\% 48,6)$, doktorlarda $(\% 27,1)$ ve hemşirelerdedir $(\% 20,5)$. Bu durum diğer sağl1k personelinde eğitim eksikliğini düşündürürken, hemşire ve doktorlarda ise usulüne uygun injeksiyon ağzı kapama ve kutuya atma konusunda zamanla risk algısının azalmasına bağlı olarak yanlış uygulamaların yapıldığını düşündürmektedir.

Çalışmamıza katılanların \%79,2'si Hepatit B'ye karşı aşı ile bağışıklanmış olduğunu belirtmiştir. Sağlık çalışanlarında kan ve vücut sivilarıyla olan mesleki temaslar ile ilgili bir çalışmada sağlık personelinin \%41.8'inin Hepatit B aşısının olmadığ 1 ve bunların önemli bir kısmının kendi serolojik durumlarını bilmediği gösterilmiştir (22). Uçak A ve arkadaşlarının çalışmasında ise Hepatit B aşılanma durumu \%85,2 olarak bulunmuştur (23). Bir başka çalışmada ise hastane personeli Hepatit B aşılanma oranı \%83'dür (24). Önal Ö'nün yapmış olduğu çalışmada Hepatit B aş1s1 olma durumu \%77,5'dir (25). Hitit Üniversitesi Eğitim ve Araştırma Hastanesinde yapılan bir çalışmada hemşirelerin \%84,2'sinin Hepatit B'ye karş1 aşılandığ1 görülmüştür (26). Türkiye'nin farklı bölgelerinde yapılan pek çok çalışmada elde edilen farklı sonuçlar personelin yaş farklılıklarını akla getirmekle birlikte, iş sağlığ 1 ve güvenliği uygulamalarındaki farklılıkları ve bir standardizasyonun sağlanamadığını da düşündürmektedir.

Araştırmamıza katılanların iş güvenliği

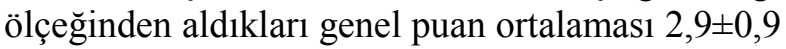
olup, en düşük alt ölçek puanları sırasıyla Faktör 1 (Mesleki Hastalıklar ve Şikayetleri) ve Faktör 4'ten (Yönetsel Destek ve Yaklaşımlar) alınmıştır. Faktör 2,3,5,6 ve 7'den ise 3,00'dan yüksek puanlar alınmıştır. Trabzon Merkez ve İlçe Devlet hastanelerinde yapılan bir çalışmada ise genel puan ortalamas1 bizden daha yüksek $(4.05 \pm 1.01)$ bulunmakla birlikte en düşük puanlar bizim çalışmamıza benzer olarak Faktör 1 ve Faktör 4'de saptanmıştır (27). Abacıgil ve ark.'nın 2015 yılında Aydın Adnan Menderes Üniversitesi Hastanesi'nde yaptığı çalışmada da bizim çalışmamıza benzer olarak genel puan ortancası 2,80 bulunmuş olup, en düşük ortancalar Faktör 1 ve Faktör 4'den elde edilmiştir (28). Özmusul'un benzer amaçla Gaziantep'te özel bir hastanede hekim dışı personelde yaptığı çalışmada ise genel puan ortalamas1 $228,03 \pm 48,57$ bulunmuş olup 6'l 1 puanlamaya göre $5,07 \pm 1,07$ 'dir. Özel hastanede elde edilen bu yüksek puan özel sektörde iş sağlığ 1 ve güvenliği uygulamalarının daha sıkı yapılmasına bağlanabileceği gibi sağlık çalışanlarının iş kaygıs1 nedeniyle daha yüksek puanlandırma yapmış olabileceğini düşündürmektedir (29).

Çalışmamızda erkek sağlık personelinin genel puan ortalaması kadınlara göre daha yüksek bulunmuştur. Öztürk ve ark. çalışma bulguları ile mevcut çalışma sonuçları benzerdir (27). Tekirdağ Namık Kemal Üniversitesi'nde yapılan bir çalışmada ise cinsiyete göre genel puan ortalamaları arasında fark bulunmamıştır (30). Bu durum Namık Kemal Üniversitesi Tıp Fakültesi hastanesinin yeni kurulmasıyla ilişkili olarak tüm sağlık çalışanlarında iş sağlığ 1 ve güvenliği uygulamalarının güncel olmasına ve risk algısının yüksekliğine bağlanabilir.

Araştırma grubumuzda çocuk sahibi olanların genel puan ortalaması ve Faktör 6 (koruyucu önlemler ve kurallar) puan ortalamas1 çocuğu olmayanlara göre daha yüksek bulunmuştur. Elde edilen bu sonuç çocuğu olanların iş sağlığı ve güvenliği uygulamaları konusunda daha duyarlı olmasindan ve kurallara 
daha fazla riayet etmesinden kaynaklanıyor olabilir.

Araştırmamızda iş sağlığı ve güvenliği ölçeği genel puan ortalaması dahili bölüm çalışanlarında cerrahi bölüm çalışanlarına göre daha düşük bulunmuştur. $\mathrm{Bu}$ durum cerrahi bölümlerde daha iyi iş sağlığı ve güvenliği uygulamalarının yapıldığını düşündürmekle birlikte dahili bölüm çalışanlarında risk algısının zamanla azalarak daha az önemsendiğinin de göstergesi olabilir. Tekirdağ Namık Kemal Üniversitesi'nde yapılan benzer bir çalışmada dahili ve cerrahi bölüm çalışanlarının genel puan ortalamaları arasında önemli bir fark saptanmamıştır (30).

Çalışmamızda sağlık çalışanlarının iş güvenliği ölçeği genel puan ortalaması ile meslek, vardiya usulü çalışma, çalışılan birim, nöbet tutma, bilgilendirilme ve iş dışı sorumluluk yüklenilmesiyle arasında ilişki saptanmadı. Ayrıca yaş, meslekte çalışma süresi, hastanede çalışma süresi, haftalık çalışma süresi, aylık gelir ve nöbet sayısı ile iş güvenliği ölçeği genel puanı arasında önemli korelasyonlar saptanmadi. Yaş kontrol altına alındığında da tüm bu değişkenlerle iş güvenliği ölçeği puanı arasında önemli korelasyonlar saptanmadi. Namik Kemal Üniversitesi'nde yapılan çalışmada da bizim çalışmamızla uyumlu olarak yaşa ve hastanede çalışma süresine göre genel puan ve alt ölçek puan ortalamaları arasında istatistiksel olarak önemli farklılıklar bulunmamıştır (30).

\section{Sonuç ve Öneriler}

Hatay Mustafa Kemal Üniversitesi Araştırma ve Uygulama Hastanesi sağl1k personelinin "Hastanelerde Çalışan Sağlık Personeli İçin İş Güvenliği Ölçeği” puan ortalaması tam puanın yarısına yakındır. Kadınların, dahili branş çalışanlarının ve çocuğu olmayanların puan ortalaması daha düşüktür. Özellikle "Mesleki Hastalıklar ve Şikayetleri" ile "Yönetsel Destek ve Yaklaşımlar" başta olmak üzere iş sağlığı ve güvenliği alanlarının iyileştirilmesi gerekmektedir.

\section{Teşekkür}

Çalışmanın literatür taraması, anket oluşturulması ve veri toplanmasında MKÜ Tıp Fakültesi İntörn Doktorları Muhammed Akay, Yağmur Atakan, Dilan Coşgun, Abdullah Çelik, Ayşegül Ekri,
Ömer Faruk Geçici, Abdurrahman Güngör, Merve Koçer, Merve Külahlığlu, Burcu Sat, Erdem Şahin, Halil Oktay Usluer ve Emre Yakut'a teşekkür ederiz.

\section{Kaynaklar}

1. İşte Sağlık Dergisi. İş Sağlığı Güvenliği ve Sorumluluklar. Temmuz 2010. (Erişim Tarihi:14.12.2017).http://www.istesaglikdergis i.com.tr/index.php/temmuz-2010/72-is-sagligiguvenligi-vesorumluluklar.

2. Sabuncuoğlu Z. İnsan kaynakları yönetimi [Human Resources Management]. Bursa: Ezgi Kitabevi;2000.

3. Abdullah NAC, Spickett JT, Rumckev KB, Dhaliwal SS. Validity and reliability of the safety climate measurement in Malaysia. International Review of Business Research Papers 2009;5:111-141.

4. Bektaş G, İşçi E, Haçıroğlu M. Tıbbi atıkların çevre sağlığına etkileri ve Haseki Devlet Hastanesi ve İ.Ü. Kardiyoloji Enstitüsü'nde hasta başına düşen tıbbi atik miktarının tespiti ile ilgili bir araştırma. Hastane Yönetimi 2005;Temmuz-Ağustos-Eylül:24-31.

5. Bahçecik, N, Öztürk, H. The occupational safety and health in hospital from the point of nurses. Colleguim Antropologicum, 2009; 33 (4): 1205-1214.

6. Uğurlu N, Y1lmaz B, Karabacak F. İki farklı hastanede çalışan hemşirelerin mesleki risk faktörlerinin belirlenmesi. İ.Ü. F.N. Hemşirelik Yüksekokulu Dergisi -2010;18:19-25.

7. Çinal A, Demir M. Hastanelerde hizmet standartları. T.C. Sağlık Bakanlığı Tedavi Hizmetleri Genel Müdürlüğü Performans Yönetimi ve Kalite Geliştirme Daire Başkanlığı, Ankara: Pozitif matbaa Ltd. Şti.; 2011.

8. Hasta ve çalışan güvenliğinin sağlanmasına dair yönetmelik. Resmi Gazete, 06 Nisan 2011, Say1 2789.

9. Özkan Ö, Emiroğlu O. Hastane Sağlık Çalışanlarına Yönelik İşçi Sağlığı Ve İş Güvenliği Hizmetleri. C.Ü.Hemşirelik Yüksekokulu Dergisi 2006, 10 (3): 43-51.

10. Gül A, Üstündağ H, Kahraman B, Pürisa S. Hemşirelerde kas iskelet ağrilarının değerlendirilmesi. HSP 2014;1:1-10.

11.Aiken LH, Clarke SP, Sloane DM. Hospital staffing, organization and quality of care: cross- 
national findings. Nurs Outlook. 2002;50:18794.

12. Pala, K. Türkiye'de İş Sağlığında Durum. TTB Mesleki Sağlık ve Güvenlik Dergisi.Temmuz 2000;3:3.

13. Öztürk H, Babacan E. Bir Ölçek Geliştirme Çalışması: Hastanede Çalışan Sağlık Personeli İçin İş Güvenliği Ölçeği. Hemşirelikte Eğitim ve Araştırma Dergisi. 2012;9(1): 36-42.

14.Deveci SE, Açık Y, Ercan E, Oğuzöncül AF. Bir Üniversite Hastanesinde Temizlik Çalışanlarının Temizlik ve Hijyen Konusundaki Davranışlarının Değerlendiril-mesi FÜ Sağ Bil Tip Derg 2010; 24(2): 123-127.

15.Pittet D. Improving compliance withh and hygiene in hospitals. Infect Control Hosp Epidemiol 2000; 21:381-386

16.Pittet D, Hugonnet S, Harbarth $S$ et al. Effectiveness of a hospital wideprogramme to improve compliance with hand hygiene. Lancet 2000; 356: 1307-1312

17.Pittet D. Compliance with hand disinfection and its impact on hospital-acquired infections. ]Hosp infect 2001; 48: 40-46.

18.Sönmezer MÇ, Gülhan B, Otuzoğlu M, Yakut HI, Tezer H. Pediatri Yoğun Bakım Ünitesindeki Sağlık Personelininin El Hijyenine Uyumunun Değerlendirilmesi. Türkiye Çocuk HastDerg/Turkish J Pediatr Dis. 2014; 2: 75-78.

19.Altıok M, Kuyurtar F, Karaçorlu S, Ersöz G, Erdoğan S. Sağlık Çalışanlarının Delici Kesici Aletlerle Yaralanma Deneyimleri ve Yaralanmaya Yönelik Alınan Önlemler, Onuncu İç Hastalıkları Kongresi, 15- 19 Ekim 2008

20.Çalışkan D, Akdur R. Ankara Ünïversitesi Tip Fak. HastanesindeÇalişanHemşirelerin Kendi Bildïrimleri İle Karşilaştiklari Mesleki Riskler. Ankara Ünïversitesi Tip Fakültesi Mecmuasi; 2001;54(2):135-142.

21.Flores A, Pevalin DJ. Healthcare workers compliance with glove use and the effect of glove use on hand hygiene compliance. $\mathrm{Br} \mathbf{J}$ Infect Control 2006; 7(6):15-9. 22. Erol S, Özkurt Z, Ertek M, Kadanalı A, Taşyaran M. Sağlık Çalışanlarında Kan ve Vücut Sivılarıyla Olan Mesleki Temaslar. Hastane İnfeksiyonları Dergisi 2005:9(2):101106.

23. Uçak A. Sağlık Personelinin Maruz Kaldığı İş Kazaları Ve Geri Bildirimlerinin
Değerlendirilmesi, Afyonkarahisar Kocate-pe Üniversitesi Sağlık Bilimleri Enstitüsü, 2009.

24.Çelik Y, Akduman D, Kıran S. Sağlık Çalışanları ve Öğrencilerin Kan ve Vücut Sıvılarıyla Bulaşan Enfeksiyonlar, Enfeksiyon Kontrol Önlemleri Hakkındaki Bilgi Düzeyleri, Temas Sıklıkları, Serolojik Durumları ve Hepatit B Aşılanma Durumlarının Değerlendirilmesi, Türkiye Klinikleri J Med Sci 2010;30(4):1246-55

25.Önal Ö. Acil Sağlık İstasyonlarında Çalışan Personelin Mesleki Risk Durumları. Journal of Contemporary Medicine 2015;5(4): 239-244 Doi: 10.16899/ctd. 46579

26.Özakar Akça1 S, Aydın Z. Eğitim ve Araştırma Hastanesinde Çalışan Hemşirelerin KesiciDelici Tıbbi Aletleri Güvenli Kullanımlarına İlişkin farkındalıkları. J ContempMed 2016; 6(4): 319-326.

27.Öztürk H, Babacan E, Anahtar EÖ. Hastanede çalışan sağlı personelinin iş güvenliği.Gümüşhane Üniversitesi Sağllk Bilimleri Dergisi / Gümüşhane University Journalof Health Sciences2012;1(4):252-268.

28. Abacıgil F, Çapacı B, Beşer E, Gürcan B, Avcil M, Uğurlu A. Sağlık personellerinin iş güvenliği algısı ve iş kazaları ile ilişkisi. 18. Ulusal Halk Sağlığı Kongresi Özet Kitabı 2015:658-659.

29. Özmusul B, Ulutaşdemir N, H Balsak. Özel bir hastanede görev yapan hekim dişı sağlık çalışanların iş sağllğ̆ ve güvenliği kapsamında karşılaștıkları risk ve tehlikelerin iş stresi düzeylerine etkisi 2015. 18. Ulusal Halk Sağlığ Kongresi, Özet Kitab1 2015;252-253.

30. Çelikkalp Ü, Varol Saraçoğlu G, Keloğlu G. Hemşirelerin çalışma ortamlarında iş güvenliği uygulamalarının değerlendirmesi. TAF Preventive Medicine Bulletin. 2016:15:1-4. 